\title{
State of the Irish Housing Stock - Modelling the heat losses of Ireland's existing detached rural housing stock \& estimating the benefit of thermal retrofit measures on this stock
}

\author{
Ciara Ahern \\ Technological University Dublin, ciara.ahern@tudublin.ie \\ Philip Griffiths \\ Ulster University, p.griffiths@ulster.ac.uk \\ Micheal O'Flaherty \\ Technological University Dublin, micheal.oflaherty@tudublin.ie
}

Follow this and additional works at: https://arrow.tudublin.ie/engschcivart

Part of the Energy Systems Commons

\section{Recommended Citation}

Ahern,C.,et al., State of the Irish housing stock - Modelling the heat losses of Ireland's existing detached rural housing stock \& estimating the benefit of thermal....Energy Policy (2013), doi:10.1016/

j.enpol.2012.11.039

This Article is brought to you for free and open access by the School of Civil and Structural Engineering at ARROW@TU Dublin. It has been accepted for inclusion in Articles by an authorized administrator of ARROW@TU

Dublin. For more information, please contact arrow.admin@tudublin.ie, aisling.coyne@tudublin.ie, gerard.connolly@tudublin.ie.

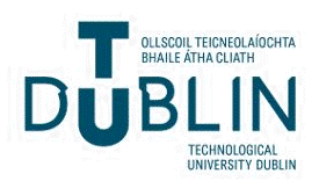




\title{
State of the Irish housing stock-Modelling the heat losses of Ireland's existing detached rural housing stock \& estimating the benefit of thermal retrofit measures on this stock
}

\author{
Ciara Ahern ${ }^{\mathrm{a},}{ }^{,}$, Philip Griffiths ${ }^{1, \mathrm{~b}}$, Micheál O’Flaherty ${ }^{2, \mathrm{a}}$ \\ a Dublin Energy Lab, Dublin Institute of Technology, School of Civil and Building Services Engineering, Rm 245, Bolton St., Dublin 1, Ireland \\ ${ }^{\mathrm{b}}$ Built Environment Research Institute, Room 4D10, School of The Built Environment University of Ulster, Jordanstown campus, Shore Road, Newtownabbey, \\ Co. Antrim, BT37 OQB, UK
}

\section{H I G H L I G H T S}

- Model constructs base geometry of detached rural Irish dwellings by age band.

- Model quantifies savings to this stock via The National Insulation Scheme.

- Results offer significant contribution to Ireland's carbon abatement projections.

- Greatest savings result from retrofitting the pre 1979 stock.

- Government needs to introduce PAYS scheme or similar to engage public at large.

\section{A R T I C L E I N F O}

\section{Article history:}

Received 24 April 2012

Accepted 16 November 2012

\section{Keywords:}

Domestic

Detached

Retrofit

\begin{abstract}
A B S T R A C T
Ireland's housing stock has been identified as being amongst the least energy efficient in Northern Europe. Consequently, atmospheric emissions are greater than necessary. Government funded schemes have been introduced to incentivise the uptake of thermal retrofit measures in the domestic Irish market. A study of Ireland's housing highlights the dominance of detached houses (43\%), $72 \%$ of which are rurally located and are predominantly heated with fuel oil. This paper investigates the economic and carbon case for thermal retrofit measures to the existing detached, oil centrally heated, rural housing stock. The study found the case for energy efficiency measures to be categorical and supports the Irish Government's focus on energy efficiency policy measures. Thermal retrofit measures in the detached housing stock have the potential to realise an averaged $65 \%$ theoretical reduction in heating costs and $\mathrm{CO}_{2}$ emissions for houses constructed prior to 1979 (coinciding with the introduction of building regulations) and around $26 \%$ for newer homes, thus offering a significant contribution (44\%) to Ireland's residential carbon abatement projections and hence in meeting the EU's directives on energy and carbon. The greatest savings (36\%) of Ireland's carbon abatement projections result from improving the energy efficiency of the pre 1979 stock.
\end{abstract} (c) 2012 Elsevier Ltd. All rights reserved.

\section{Introduction}

Ireland's housing stock has been identified as being amongst the least energy efficient in Northern Europe (Brophy et al., 1999; Lapillonne et al., 2012); therefore energy consumption in the domestic sector is greater than necessary (Clinch and Healy, 2004, 2000). Examining $\mathrm{CO}_{2}$ emissions per dwelling, the average Irish dwelling in 2005 emitted $47 \%$ more $\mathrm{CO}_{2}$ than the average

\footnotetext{
${ }^{*}$ Corresponding author. Tel.: +353872046565.

E-mail addresses: ciara.ahern@dit.ie (C. Ahern)

p.griffiths@ulster.ac.uk (P. Griffiths), micheal.oflaherty@dit.ie (M. O’Flaherty).

1 Tel.: +442890368288.

2 Tel.: +35314023830
}

dwelling in the UK. Emissions were 92\% higher than the average for the EU-15 and 104\% more than the EU-27 (SEAI, 2008).

Regulations governing the energy efficiency of new dwellings were not introduced in the Republic of Ireland until $1979.50 \%$ of the current housing stock was constructed prior to 1979 and it was not until 2006 that significant thermal retrofits were introduced. Hence most houses in Ireland are considered to be thermally substandard (Brophy et al., 1999, Clinch and Healy, 2000).

Ireland's recently published (2009) National Energy Efficiency Action Plan 2009-2020 (NEEAP) identifies the following major energy efficiency challenges in the Irish Residential Sector:

1. To create a generation of buildings that meet expectations of comfort and functionality while significantly reducing energy usage and $\mathrm{CO}_{2}$ emissions; and 


\section{Nomenclature}

\section{S Single storey}

2S Two storey

$\mathrm{ACH}_{50}$ Air exchange rate per hour resulting from a pressure difference of $50 \mathrm{~Pa}$ between the inside and outside of the building, including the effects of air inlets

$\mathrm{ACH}$ Air exchange rate per hour induced by wind of a normally exposed site between the inside and outside of the building, including the effects of air inlets

$A_{\mathrm{f}} \quad$ Floor area $\left(\mathrm{m}^{2}\right)$

$A_{\text {ope }} \quad$ Maximum combined area of doors windows and rooflights $\left(\mathrm{m}^{2}\right)$

BER Building energy rating

BRE Building research establishment

CIBSE Chartered institute of building services engineers

CSO Central statistics office of Ireland

DCENR Department of communications, energy and natural resources

DEAP Dwelling energy assessment procedure

DG Double glazed

EDRT Energy demand reduction target

$e_{\mathrm{k}} \quad$ Default correction factor for exposure

EPBD Energy performance of buildings directive

EPC Energy performance coefficient

ESB Electricity supply board

ESRI Economic and social research institute of Ireland

EU-15 The 15 countries that were members of the EU before the enlargement on 1st May 2004

EU-27 Total EU member countries as of time of publication $\mathrm{fg}_{1}$

Default correction factor taking into account the influence from annual variation of the external temperature

$\mathrm{fg}_{2} \quad$ Temperature reduction factor taking into account the difference between annual mean external temperature and external temperature

$G_{\mathrm{w}} \quad$ Correction factor taking into account the influence from ground water.

$H_{\mathrm{T}, \mathrm{ig}} \quad$ Heat loss coefficient through the ground (W/K)

IEA International Energy Agency

IES Integrated environmental solutions

INSHQ Irish National Survey of Housing Quality

$k \quad$ Soil thermal conductivity $(\mathrm{W} / \mathrm{m} \mathrm{K})$

$\mathrm{koe} / \mathrm{m}^{2} \quad$ Kilogramme of oil equivalent per metre squared

MPEPC Maximum permitted energy performance coefficient

NEEAP National energy efficiency action plan

PAYS Pay As You Save

$R_{\mathrm{si}} \quad$ Internal wall surface thermal resistance $\left(\mathrm{m}^{2} \mathrm{~K} / \mathrm{W}\right)$

$R_{\mathrm{se}} \quad$ External wall surface thermal resistance $\left(\mathrm{m}^{2} \mathrm{~K} / \mathrm{W}\right)$

RSD Ratio of Standard Deviation over the mean

SAP UK Standard Assessment Procedure

SEAI Sustainable Energy Authority of Ireland (formerly Sustainable Energy Ireland-SEI)

SG Single glazed

toe/dw Tonnes of oil equivalent per dwelling

UCD University College Dublin

Uope Average $U$-Value of windows, doors and rooflights $\left(\mathrm{W} / \mathrm{m}^{2} \mathrm{~K}\right)$

$U_{\mathrm{m}} \quad$ Maximum average $U$-Value $\left(\mathrm{W} / \mathrm{m}^{2} \mathrm{~K}\right)$

$V \quad$ Volume $\left(\mathrm{m}^{3}\right)$
2. To address the legacy of older housing with poor energy and $\mathrm{CO}_{2}$ performance.

The recent downturn in the Irish economy combined with the oversupply of new dwellings has resulted in an average vacancy rate of $15 \%$ (over $260 \mathrm{~K}$ homes) and a collapse in new house building (Fitzgerald, 2005; Kitchen et al., 2010; CSO, 2011). Given that in some locations it could well be over a decade or more before excess housing stock becomes occupied, depending on an economic recovery, liquidity amongst lenders, and demographic demand (Kitchen et al., 2010), if a significant reduction in energy consumption of the domestic housing sector is to occur, then it will be necessary to undertake extensive thermal refurbishment (retrofitting) of the current housing stock. (Beddington, 2008; Gupta, 2009, 2010; Bernier et al., 2010; Curtain, 2009; Bell and Lowe, 2000). The Irish government has thus introduced The National Insulation Scheme designed to encourage home owners to increase the efficiency of the existing housing stock.

A large contributing factor to the high energy consumption of the typical Irish home is that the nation's housing stock has larger than average floor areas; the average (useful floor area) size of an Irish dwelling being $104 \mathrm{~m}^{2}$ in 2003 representing the fourth largest figure in Europe behind Luxembourg, Denmark, and Malta. Also Ireland has on average the greatest number of rooms in Europe at 5.6 rooms per person in 2002 (Federcasa, 2006).

Another key variable impacting on energy consumption in the residential sector is the type of dwelling. Detached dwellings normally have a greater floor area than other dwelling types; they also have high surface area to volume ratios and thus have a greater heat loss in $\mathrm{W} / \mathrm{K}$, than other house types of the same construction period. A seminal study by Shipworth et al. (2010) found that detached homes have a tendency to be heated for longer than other house types and Scott et al. (2008) found they have a stronger association with fuel poverty than semi-detached houses, apartments or bedsits; indeed, based on an expenditure index, inhabitants of flats and apartments are two-thirds less likely to be fuel poor than those in detached houses, all other things being equal. Detached dwellings should therefore be particularly targeted in energy-efficiency retrofit programmes (Lomas, 2010; Shipworth et al., 2010).

The higher running costs associated with detached dwellings and the pervasiveness of this dwelling type in the Irish landscape is an indicator of why Ireland is said to have such a high degree of fuel poverty; approximately 150,000 homes were estimated to be experiencing fuel poverty in 2005 (Curtain, 2009). This trend is exacerbated by the residents of the older housing being elderly, retired and often widowed occupants who are asset rich and cash poor. Furthermore, Ireland has an ageing population, currently $11 \%$ of the population are aged 65 and over and this is set to increase to 25\% by 2060 (Begley, 2011).

An analysis of Ireland's housing stock shows that $43 \%$ are detached properties and of this $43 \%, 72 \%$ are rurally located. Furthermore $70 \%$ of this house type was constructed prior to the introduction of the building regulations (CSO 2006). Due to the prevalence and relative inefficiency of detached housing in Ireland; this study will analyse these dwellings, seeking to quantify the effectiveness of thermal retrofits.

\section{Methodology}

A full physical description for Irish dwellings does not exist from any one source. Creating a base geometry and set of thermal 
characteristics for detached dwellings was therefore a major piece of the work undertaken in this study.

A base geometry based on a sampling of rural detached dwellings was created. A set of thermal characteristics were then applied to this base geometry according to age bands; assuming similar characteristics of construction. The age bands were based on Ireland's national Dwelling Energy Assessment Procedure, (DEAP). DEAP is Ireland's implementation of the EU directive on the Energy Performance of Buildings (Directive 2002/91/EC

Table 1

The base geometry a standard Irish domestic detached dwelling.

\begin{tabular}{|c|c|c|c|c|c|c|c|c|c|}
\hline \multirow{3}{*}{$\begin{array}{l}\text { DEAP } \\
\text { age } \\
\text { band }\end{array}$} & \multirow{3}{*}{$\begin{array}{l}\text { DEAP year of } \\
\text { construction }\end{array}$} & \multicolumn{8}{|c|}{ Area $\left(\mathrm{m}^{2}\right)$} \\
\hline & & \multicolumn{3}{|c|}{ Single storey } & \multicolumn{3}{|c|}{ Two storey } & \multicolumn{2}{|l|}{ Common } \\
\hline & & Wall & Roof & Floor & Wall & Roof & Floor & Window & Door \\
\hline A & Before 1900 & 97 & 149 & 142 & 147 & 75 & 71 & 24 & 5.7 \\
\hline B & 1900-1929 & 97 & 149 & 142 & 147 & 75 & 71 & 24 & 5.7 \\
\hline C & 1930-1949 & 97 & 149 & 142 & 147 & 75 & 71 & 24 & 5.9 \\
\hline $\mathrm{D}$ & 1950-1966 & 98 & 151 & 143 & 148 & 75 & 72 & 24 & 5.9 \\
\hline $\mathrm{E}$ & 1967-1977 & 99 & 155 & 147 & 151 & 77 & 74 & 24 & 6.1 \\
\hline $\mathrm{F}$ & 1978-1982 & 105 & 160 & 152 & 157 & 80 & 76 & 21 & 6.1 \\
\hline G & 1983-1993 & 105 & 164 & 156 & 158 & 82 & 78 & 22 & 5.9 \\
\hline $\mathrm{H}$ & 1994-1999 & 109 & 183 & 174 & 165 & 91 & 87 & 25 & 6.3 \\
\hline I & 2000-2004 & 115 & 204 & 194 & 174 & 102 & 97 & 27 & 6.8 \\
\hline $\mathrm{J}$ & $2005-2006$ & 120 & 230 & 219 & 182 & 115 & 110 & 31 & 6.8 \\
\hline
\end{tabular}

Data from various sources, refer to Table 3.
EPBD). See Tables 1 and 2 for the summary base geometry and thermal characteristics established for Irish detached dwellings by DEAP age band.

Tables 1 and 2 were compiled using datasets which were provided by University College Dublin's Energy Research Institute, these included the 2006 national census (CSO 2006) and the Irish National Survey of Housing Quality 2001-2002 (INSHQ). Other data sources were the DEAP manual, and the UK's Building Research Establishment (BRE) publications. Table 3 summarises the data used.

The central statistics office (CSO) census data relates the total number of detached rural centrally heated dwellings in Ireland (totalling 406,910 dwellings) by age and floor area. The age bands used by DEAP differ from the age bands quoted in the CSO dataset, therefore an adjustment had to be made so that U-values as ascribed in DEAP could be attributed to actual census housing quantities; the average number of houses built in a CSO construction period was found and then the number of houses was redistributed in line with DEAP age groups, see Table 4 .

The INSHQ (sample set of over 40,000) asked much more detailed questions pertaining to the heating, hot water and comfort systems than the CSO, the results from this dataset were extrapolated and applied to housing quantities outlined in Table 4 by DEAP age band. The statistics package SPSS ${ }^{\circledR}$ was used to manipulate information contained in the datasets.

The BRE was used to establish infiltration rates (sample set of 471 dwellings) and glazing ratios were established from the UK Standard Assessment Procedure (SAP) database; again applied by DEAP age band.

Table 2

Thermal characteristics of a standard Irish domestic detached dwelling.

\begin{tabular}{|c|c|c|c|c|c|c|c|c|c|}
\hline \multirow[t]{3}{*}{ DEAP age band } & \multirow[t]{3}{*}{ DEAP year of construction } & \multicolumn{7}{|c|}{$U$-Values $\left(\mathrm{W} / \mathrm{m}^{2} \mathrm{~K}\right)$} & \multirow[t]{3}{*}{ Infiltration rate $\mathrm{ACH}_{50}$} \\
\hline & & \multirow[t]{2}{*}{ Wall } & \multirow[t]{2}{*}{ Roof } & \multirow[t]{2}{*}{ Door } & \multicolumn{2}{|l|}{ Floor $^{\mathrm{a}}$} & \multicolumn{2}{|l|}{ Window } & \\
\hline & & & & & Single storey & Two storey & Single glazed & Double glazed & \\
\hline A & Before 1900 & 2.10 & 2.30 & 3.0 & 0.68 & 0.84 & 4.80 & 3.10 & 12 \\
\hline $\mathrm{B}$ & $1900-1929$ & 2.10 & 2.30 & 3.0 & 0.68 & 0.84 & 4.80 & 3.10 & 12 \\
\hline C & 1930-1949 & 2.10 & 2.30 & 3.0 & 0.68 & 0.84 & 4.80 & 3.10 & 16 \\
\hline $\mathrm{D}$ & 1950-1966 & 2.10 & 2.30 & 3.0 & 0.67 & 0.84 & 4.80 & 3.10 & 14 \\
\hline $\mathrm{E}$ & 1967-1977 & 2.10 & 2.30 & 3.0 & 0.67 & 0.83 & 4.80 & 3.10 & 14 \\
\hline $\mathrm{F}$ & 1978-1982 & 1.10 & 0.40 & 3.0 & 0.52 & 0.63 & 4.80 & 3.10 & 12 \\
\hline G & 1983-1993 & 0.60 & 0.40 & 3.0 & 0.52 & 0.63 & 4.80 & 3.10 & 10 \\
\hline $\mathrm{H}$ & 1994-1999 & 0.55 & 0.35 & 3.0 & 0.37 & 0.43 & 4.80 & 3.10 & 10 \\
\hline I & 2000-2004 & 0.55 & 0.35 & 3.0 & 0.36 & 0.42 & 4.80 & 3.10 & 10 \\
\hline $\mathrm{J}$ & $2005-2006$ & 0.37 & 0.25 & 3.0 & 0.31 & 0.34 & 4.80 & 3.10 & 10 \\
\hline
\end{tabular}

Data from various sources, refer to Table 3.

a Wall thickness taken as $300 \mathrm{~mm}$; soil type taken as DEAP default—thermal conductivity $2.0 \mathrm{~W} / \mathrm{m} \mathrm{K} R_{\mathrm{si}}-0.17 \mathrm{~m}{ }^{2} \mathrm{~K} / \mathrm{W}$ and $R_{\mathrm{se}}-0.04 \mathrm{~m}{ }^{2} \mathrm{~K} / \mathrm{W}$; presence of floor insulation and thickness as per Table S6 in DEAP.

Table 3

Data Sources used in heat loss model.

\begin{tabular}{|c|c|c|c|c|}
\hline Central Statistics Office & $\begin{array}{l}\text { Irish National Survey of Housing } \\
\text { Quality (INSHQ) 2001-2002 }\end{array}$ & DEAP Manual & $\begin{array}{l}\text { Building Research } \\
\text { Establishment }\end{array}$ & $\begin{array}{l}\text { EN I2831:2003 Heating } \\
\text { Systems in } \\
\text { buildings-method for } \\
\text { calculation of design heat } \\
\text { load }\end{array}$ \\
\hline $\begin{array}{l}\text { Number of centrally heated } \\
\text { detached rural housing in } \\
\text { Ireland }\end{array}$ & $\begin{array}{l}\text { Single or two storey (established } \\
\text { from presence of a stairs) }\end{array}$ & $\begin{array}{l}U \text {-values for the different age } \\
\text { bands of the existing housing } \\
\text { stock }\end{array}$ & Infiltration rates $\left(\mathrm{ACH}_{50}\right)$ & $\begin{array}{l}\text { Correction factor for annual } \\
\text { variation of external } \\
\text { temperature }\left(f g_{1}\right)\end{array}$ \\
\hline Dwelling age & Floor areas predating 1980 & Internal temperature & Glazing ratios & \\
\hline \multirow[t]{2}{*}{$\begin{array}{l}\text { Planning permission } \\
\text { office-floor areas post dating } \\
1980\end{array}$} & $\begin{array}{l}\text { Window typeType of heating } \\
\text { system }\end{array}$ & & & \\
\hline & Number of external doors present & & & \\
\hline
\end{tabular}


Table 4

CSO detached housing quantities corrected by DEAP age band. Source: CSO 2006

\begin{tabular}{lllll}
\hline $\begin{array}{l}\text { CSO year of } \\
\text { construction } \\
\text { (Inclusive of 'not } \\
\text { stated') }\end{array}$ & $\begin{array}{l}\text { Total no. of } \\
\text { detached houses } \\
\text { built in that } \\
\text { period }\end{array}$ & $\begin{array}{l}\text { DEAP } \\
\text { age } \\
\text { band }\end{array}$ & $\begin{array}{l}\text { DEAP year } \\
\text { of } \\
\text { construction }\end{array}$ & $\begin{array}{l}\text { Total no of } \\
\text { detached houses } \\
\text { built in that } \\
\text { period }\end{array}$ \\
\hline $\begin{array}{l}\text { before } 1919 \\
1919 \text { to } 1940\end{array}$ & 61,802 & A & before 1900 & 44,784 \\
$1941-1960$ & 35,068 & B & $1900-1929$ & 34,552 \\
$1961-1970$ & 23,154 & C & $1930-1949$ & 32,453 \\
$1971-1980$ & 61,596 & D & $1950-1966$ & 32,245 \\
$1981-1990$ & 56,693 & E & $1967-1977$ & 52,457 \\
$1991-1995$ & 24,798 & F & $1978-1982$ & 29,817 \\
$1996-2000$ & 44,719 & G & $1983-1993$ & 60,233 \\
2001 or later & 65,730 & H & $1994-1999$ & 45,694 \\
& & J & $2000-2004$ & 52,764 \\
& 406,910 & & $2005-2006$ & 21,910 \\
& & & & 406,910 \\
\hline
\end{tabular}

Using default thermal characteristics thus established, combined with an International Weather for Energy Calculation (IWEC) file for Dublin, the heat load for a statistical occupancy and year was established by DEAP age band.

On the basis that improvements to energy efficiency are found to offer the cheapest and most readily available carbon abatement opportunities (SEAI, 2009) and in line with Ireland's National Energy Efficiency Action Plan, the same dwellings were then remodelled assuming that the occupant had availed of the government grant aided National Insulation Scheme.

Concurrently with the fabric improvement measures it was also assumed that the occupant reduced the infiltration rate of the dwelling. More detailed information regarding the thermal retrofit measures is outlined in Section 2.5.

To calculate the heat load of the dwellings a modified version of The European Design Standard was used - BS-EN 12831:2003 Heating Systems in buildings - Method for calculation of design heat load which is referenced in BS EN 15450:2007.

The main parameters of this calculation are outlined below

- Areas of fabric elements

- $U$-values of fabric elements

- Infiltration rates

- Thermal bridging factors

- Internal temperature

- External temperature

The prescribed calculation was modified in the following manner;

- Exact details of dwelling construction are unknown so a default $U$-Value prescribed in DEAP was used to calculate thermal bridging. The default value of $y=0.15 \mathrm{~W} / \mathrm{m}^{2} \mathrm{~K}$ was applied to all dwellings. The total surface area in this case excludes the ground floor.

- $\mathrm{T}$ to allow translation between air permeability $\left(\mathrm{m}^{3} / \mathrm{h} \cdot \mathrm{m}^{2}\right)$ and air change rates at $50 \mathrm{~Pa}$ pressure difference (ACH50) Ventilation heat loss was calculated using the formula $Q=1$ / $3(\mathrm{ACH}) \mathrm{V} \Delta \mathrm{t}$.

Default correction factors were as follows; $f g_{1}=1.45, f_{2}=0.48$ and $G_{\mathrm{W}}=1.00$ Therefore $f \mathrm{~g}_{1} f_{2} \mathrm{G}_{\mathrm{W}}=0.7$.

\subsection{Dwelling envelope characteristics and areas}

The CSO Planning Permission office holds data on floor areas from 1980 to the present day. For floor areas predating 1980 it was necessary to refer to the INSHQ. Positive responses to the existence of a staircase in the INSHQ were used to establish the number of storeys. On average $42 \%$ of the detached dwelling stock are single storey and 58\% have two storeys. The results show that the trend of increasing floor area with time is followed within this housing category (SEAI, 2008).

The dwellings were assumed to be rectangular in construction with a length twice the width; this assumption was confirmed by an analysis of rural large scale ordinance survey maps. The average ground floor area for a one storey dwelling was found to be $161 \mathrm{~m}^{2}$ and the average for a two storey was found to be $81 \mathrm{~m}^{2}$. The floor is assumed to be a solid ground floor. Default $U$-values by date of construction were interpolated from DEAP Table S8 using exposed perimeter to area ratio ( $P / A$ ratio)

DEAP states that if the wall type cannot be identified or does not fit into any particular category to assume wall type is 'stone'. Referencing Table S3 in DEAP, insulated stone and cavity wall behave similarly; there is a significant thermal improvement only where insulation is present; it was therefore necessary to quantify the presence of cavity insulation by DEAP age band. The INSHQ was used to correlate year of construction with presence of a cavity wall and cavity insulation. The presence of cavity walls steadily increases over time; the presence of infill cavity insulation however is slow to catch up. The effect of the draft and actual Building Regulations in the mid 1970's is notable with the presence of cavity walls jumping to over $70 \%$, with the presence of insulation at approx 90\% (see Fig. 1). An analysis of cavity wall (without insulation) corresponds with that of stone type wall, which supports DEAP's assumption that unidentified/unknown wall types can use the default values of 'stone'.

In the absence of an Irish dataset, glazing ratios were extracted from Table S4 of the UK Standard Assessment Procedure (SAP, 2005) on the assumption that the UK and Irish Housing Stock are similar. Irish Building regulations quote a typical storey height of $2.4 \mathrm{~m}$, thus wall area net of glazing was calculated.

Default window $U$-values for various window construction types were taken from the DEAP Manual. The default values for timber frame and PVC are the same. The predominant window types across all age bands are timber and PVC (INSHQ). The $U$ value for all single glazing was taken as $4.8 \mathrm{~W} / \mathrm{m}^{2} \mathrm{~K}$. The $U$-value for double glazing was taken as follows;

- House Bands A-I (Pre 2004 double glazing) assumed to be timber frame/PVC at a $U$-value of $3.1 \mathrm{~W} / \mathrm{m}^{2} \mathrm{~K}$.

- House Band J (Post 2004 double glazing) was assumed to be low $\mathrm{E}$, hard coat, air filled glazing with an associated $U$-value of $2.2 \mathrm{~W} / \mathrm{m}^{2} \mathrm{~K}$ (DEAP).

- Retrofit glazing was assumed to be $4 \mathrm{~mm}$ low $\mathrm{E}$, argon filled with an associated $U$-value of $2.2 \mathrm{~W} / \mathrm{m}^{2} \mathrm{~K}$.

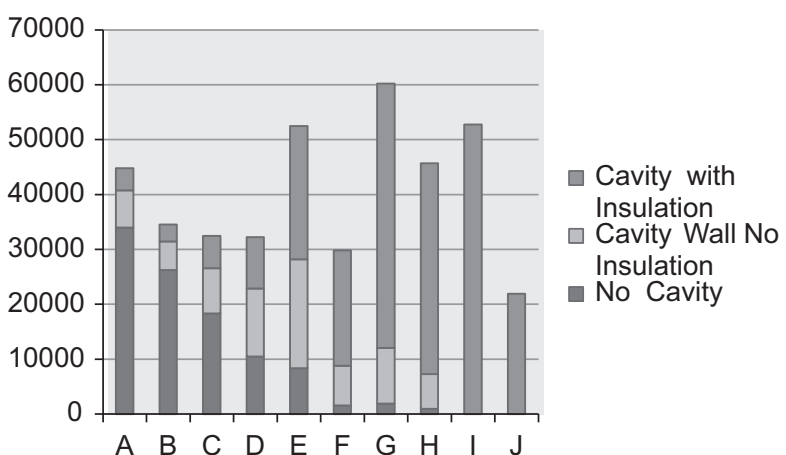

Fig. 1. Corrected quantity of detached dwellings by wall type and DEAP age band. Source: INSHQ 2001-2002. 
Using the INSHQ dataset an analysis was undertaken to establish the pervasiveness of double glazing. Notably, the prevalence of double glazing increases with time; however there is evidence of a large degree of retrofitting in pre-1940 houses which would have been originally constructed with single glazing. INSHQ data is available up to the year 2001; it is assumed that all houses built after 2001 are double glazed and compliant with the building regulations at time of construction. The percentages established from the smaller INSHQ dataset were applied to the larger CSO (2006) dataset to obtain the quantities of rural detached houses by glazing type and hence the data was correlated to DEAP age bands. A large percentage (36\%) of all detached housing remained single glazed in 2002 , of this $36 \%, 72 \%$ are in the DEAP age bands A-E (1900-1977). Table 5 depicts quantities of housing with single and double glazing by category.

All roofs were assumed to have an $18^{\circ}$ typical pitch (based upon current Irish building regulations) this resulted in the roof area being typically 5\% larger than the floor area. In 2001, $82 \%$ of detached housing in Ireland had roof insulation (Clinch and Healy, 2004), consequently all roofs are assumed to be insulated, moreover DEAP does not quote $U$-values for uninsulated roofs, therefore default roof $U$-values for insulated roofs were taken from Table S5 of DEAP with insulation thickness unknown.

The INSHQ was used to establish the typical number of doors present by dwelling type and dwelling age. DEAP states that single doors can be assumed to have an area of $1.85 \mathrm{~m}^{2}$ with double doors being twice that. For this study, doors are assumed to be solid wooden doors with a $U$-value of $3 \mathrm{~W} / \mathrm{m}^{2}{ }^{\circ} \mathrm{C}$. In order to conservatively account for the presence of a double patio door (not quantified in the INSHQ study) one door is assumed to be double with the remainder being single. Referencing Table 2; average door area of detached housing was found to be approximately $6 \mathrm{~m}^{2}$.

Table 1 shows the increasing floor, window and door area over time.

\subsection{Infiltration rates and Irish dwellings}

No Irish or UK database which specifically focuses on infiltration rates of detached dwellings exists (Pan, 2010). There is one, recently published, statistically small (28 dwellings) database for air tightness on Irish housing available (Sinnott and Dyer, 2012) which was focused on single family residential semi-detached and terraced houses. Only two large scale $(>200)$ databases for air infiltration rates in pre-2006 UK dwellings are known: one held by British Gas plc covering some 217 dwellings (Etheridge et al., 1987) and the other held by BRE covering 471 dwellings. The published data from the British Gas database compares well with the BRE data but is somewhat limited in detail (Stephen, 1998). The BRE database grouped the tested dwellings by age band. The majority of the dwellings in the BRE air leakage database, as in the UK generally, are of semi-detached, terraced and apartment type construction. It was not possible to isolate typical infiltration rates for detached housing from the databases.

In general the test infiltration rates recorded on the Irish database are lower than that of the BRE database; however the Irish database, with only 28 dwellings recorded, is not considered statistically significant. Therefore, on the assumption that Irish and UK housing construction methods differ little, the results from the cumulative distributions of 50 Pascal air change rates $\left(\mathrm{ACH}_{50}\right)$ for the 471 dwellings on the BRE database were extrapolated and reconfigured over the DEAP age bands; see Table 2 for summary results.

The infiltration rate of BRE tested homes generally lies between 10 and 16 air changes per hour at $50 \mathrm{~Pa}$ pressure difference $\left(\mathrm{ACH}_{50}\right)$, the average of the BRE sample of dwellings was $14.8 \mathrm{ACH}_{50}$ (Uglow, 1989) this indicates that the degree of air tightness of UK, and by assumption Irish Dwellings is low (EN 12831:2003 E).

Air Permeability, measured in $\mathrm{m}^{3} /\left(\mathrm{h} \cdot \mathrm{m}^{2}\right)$ at $50 \mathrm{~Pa}$ pressure difference, is the physical property used to measure air-tightness of the building fabric and is the term used within the current building regulations. It is defined as 'air leakage rate per envelope area at the test pressure differential across the building envelope of 50Pa' (Note: Envelope area is inclusive of ground floor area). Using ACR $_{50}$ divisors for 1 and 2 storey dwellings of 20.6 and 17 (Table 4.21 of CIBSE Guide A) the air permeability of the existing detached Irish housing stock was calculated, see Fig. 2.

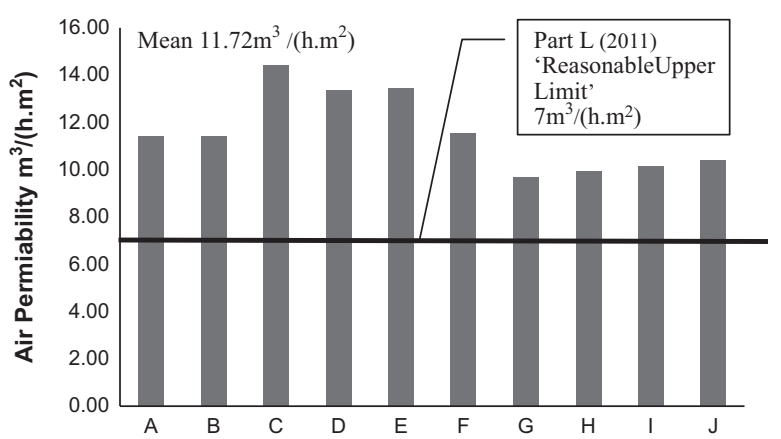

Fig. 2. Estimated air permeability of detached housing categories $\mathrm{m}^{3} /\left(\mathrm{h} \cdot \mathrm{m}^{2}\right)$ by DEAP age band.

Table 5

Dwelling age by window type by DEAP age band. Source: INSHQ 2001-2001/CSO 2006.

\begin{tabular}{|c|c|c|c|c|c|c|}
\hline $\begin{array}{l}\text { INSHQ year of } \\
\text { construction }\end{array}$ & $\begin{array}{l}\text { (\%) Single } \\
\text { glazed }\end{array}$ & $\begin{array}{l}\text { (\%) double } \\
\text { glazed }\end{array}$ & $\begin{array}{l}\text { DEAP age band } \\
\text { (Double glazed) }^{\mathrm{a}}\end{array}$ & $\begin{array}{l}\text { Corrected no. of double } \\
\text { glazed houses }\end{array}$ & $\begin{array}{l}\text { DEAP age band } \\
{\text { (Single glazed })^{\mathrm{a}}}\end{array}$ & $\begin{array}{l}\text { Corrected no. of sinlge } \\
\text { glazed Houses }\end{array}$ \\
\hline \multirow[t]{3}{*}{ Pre 1940} & 52 & 48 & $A_{D G}$ & 23,109 & $A_{S G}$ & 21,675 \\
\hline & 52 & 48 & $\mathrm{~B}_{\mathrm{DG}}$ & 17,829 & $\mathrm{~B}_{\mathrm{SG}}$ & 16,723 \\
\hline & 52 & 48 & $\mathrm{C}_{\mathrm{DG}}$ & 18,775 & $\mathrm{C}_{\mathrm{SG}}$ & 13,678 \\
\hline \multirow[t]{2}{*}{$1941-1970$} & 65 & 35 & $\mathrm{D}_{\mathrm{DG}}$ & 21,024 & $\mathrm{D}_{\mathrm{SG}}$ & 11,221 \\
\hline & 65 & 35 & $\mathrm{E}_{\mathrm{DG}}$ & 34,116 & $\mathrm{E}_{\mathrm{SG}}$ & 18,341 \\
\hline 1971-1980 & 65 & 35 & $\mathrm{~F}_{\mathrm{DG}}$ & 20,300 & $\mathrm{~F}_{\mathrm{SG}}$ & 9,518 \\
\hline \multirow[t]{5}{*}{ 1980-1996 } & 73 & 27 & $G_{D G}$ & 44,030 & $\mathrm{G}_{\mathrm{SG}}$ & 16,203 \\
\hline & 73 & 27 & $\mathrm{H}_{\mathrm{DG}}$ & 39,923 & $\mathrm{H}_{\mathrm{SG}}$ & 5,772 \\
\hline & & & $\mathrm{I}_{\mathrm{DG}}$ & 52,246 & $\mathrm{I}_{\mathrm{SG}}$ & 517 \\
\hline & & & $\mathrm{J}_{\mathrm{DG}}$ & 21,910 & $\mathrm{~J}_{\mathrm{SG}}$ & 0 \\
\hline & & & & 293,262 & & 113,648 \\
\hline
\end{tabular}

a SG and DG denotes single glazing and double glazing, respectively. The age bands used by DEAP differ from the age bands quoted in the CSO and INSHQ datasets. The average number of houses built in that period was found and then the number of houses was redistributed in line with DEAP age groups. 
All of the dwellings exceed the 'reasonable upper limit' for air permeability referred to the Technical Guidance Document Part L (2011) of $7 \mathrm{~m}^{3} /\left(\mathrm{h} \cdot \mathrm{m}^{2}\right)$ at $50 \mathrm{~Pa}$ (DECLG, 2011). The mean between dwelling types used in this study is $11.72 \mathrm{~m}^{3} /\left(\mathrm{h} \cdot \mathrm{m}^{2}\right)$, this figure correlates well with the UK mean air permeability if $11.5 \mathrm{~m}^{3}$ / $\left(\mathrm{h} \cdot \mathrm{m}^{2}\right)$ (Johnston et al., 2011).

\subsection{Occupancy Profile}

The typical occupancy profile was established from a study carried out in 2009 by Shipworth et al. (2010). The study found that the average dwelling has the heating system operating from 06:45 to $09: 45$ in the mornings and from $15: 45$ to $19: 30$ in the afternoons totalling $6.75 \mathrm{~h}$; however it found that detached houses have the heating system operating longer with an average of $8.7 \mathrm{~h}$ per day. The study found that heating duration was generally independent of year of construction. To account for the longer running hours associated with detached housing it was assumed that heating came on earlier and switched off later. The assumed hours of operation of the heating system in the model were $06: 00 \mathrm{~h}$ to $10: 00 \mathrm{~h}$ and $15: 00 \mathrm{~h}$ to $20: 00 \mathrm{~h}$ totalling $9 \mathrm{~h}$.

\subsection{Design temperatures}

An outdoor design condition of $-3{ }^{\circ} \mathrm{C}$ was selected. In a statistical Irish weather year for Dublin, between the hours of 7 am and $10 \mathrm{pm}$ the outdoor temperature only falls below $-3{ }^{\circ} \mathrm{C}$ for $4 \mathrm{~h}$ annually. Default internal design temperatures are given in Annex D (Table D.2) of EN 12831:2003; a default value of $20^{\circ} \mathrm{C}$ was used. This allows some capacity in the system if the outdoor temperature drops to $-4{ }^{\circ} \mathrm{C}$ the internal temperature will fall to $19{ }^{\circ} \mathrm{C}$, which is acceptable considering houses are generally only currently achieving a maximum indoor temperature of $18.8^{\circ} \mathrm{C}$ (SEAI, 2008). The Shipworth et al. (2010) study confirmed the selection of the internal temperature set point of $20^{\circ} \mathrm{C}$ finding that UK homes are generally heated to $19.7^{\circ} \mathrm{C}$.

In accordance with The Chartered Institution of Building Services Engineering (CIBSE) guidelines (CIBSE Guide F), it was also assumed that the heating system is not required when the outdoor temperature is greater than $15^{\circ} \mathrm{C}$.

\subsection{Thermal retrofit measures}

\subsubsection{Fabric improvement measures}

Fabric improvement measures that were considered were as follows;

- Wall insulation

- Roof insulation

- Floor insulation

- Replacing single glazing with double glazing

A practical approach was taken with improvement measuresfor instance due to the high cost and relative inconvenience to the occupier of replacement floor coverings and in line with the findings of Clinch and Healy (2004) who found there was a low penetration of floor insulation retrofits in Irish homes (with just a quarter of Irish homes so equipped). It was assumed that floor $U$-values remain static.

The Fabric $U$-Values for the roof and walls were brought in line with, The Irish National Insulation Programme-Better Energy Homes, grant aided scheme administered by SEAI (SEAI 2011) which policy makers hope will encourage refurbishment of existing homes. $U$-values for rafter and flat roof fitted insulation differ (0.2 and $0.16 \mathrm{~W} / \mathrm{m}^{2} \mathrm{~K}$, respectively). A 50/50 split on rafter and flat roof distribution was assumed therefore roof $U$-values were globally reduced to $0.18 \mathrm{~W} / \mathrm{m}^{2} \mathrm{~K}$. All wall $U$-values were brought to $0.27 \mathrm{~W} / \mathrm{m}^{2} \mathrm{~K}$, it is assumed that cavity wall infill insulation or external insulation cladding is employed to achieve this reduced wall $U$-value.

It is assumed that due to the high cost of replacing glazing that if the dwelling is already fitted with double glazing at the time of the INSHQ (2001-2002), then no adjustment to the $U$-value was made (even if the $U$-value is relatively poor compared to the modern double glazing available on the market today). If the house is single glazed, the glazing was replaced with double glazing achieving a $U$-value of $2.2 \mathrm{~W} / \mathrm{m}^{2} \mathrm{~K}$.

\subsubsection{Infiltration rate measures}

An SEAI pilot study carried out by Energy Action (2010) found that there was no correlation between retrofitting external wall insulation and improving infiltration rates. It is assumed that as part of the thermal upgrade on the property that the air tightness of the building envelope is increased by the following means (Johnston et al., 2011):

- Sealing the junction between the skirting board and the floors with an appropriate sealant.

- Fitting a compressible seal complete with an appropriate locking mechanism to the loft hatch (where present) and sealing service penetrations using an appropriate sealant.

No account is taken of improved air tightness with replacement glazing and assumed weatherstripping. Even though weatherstripped dwellings have lower infiltration rates than those without weatherstripping, the effect is nowhere near as pronounced as the effect of construction type. This is because weatherstripping is usually only applied to components (windows and doors) and it is known the majority of leakage occurs through background (adventitious) openings (Stephen, 1998).

There exists a wide range of air tightness standards in Ireland and other countries. They range from the current (2011) Irish building regulations which suggest a 'reasonable upper limit' of $7 \mathrm{~m}^{3} / \mathrm{h} \cdot \mathrm{m}^{2}$, to less than $1 \mathrm{~m}^{3} / \mathrm{h} \cdot \mathrm{m}^{2} @ 50 \mathrm{~Pa}$ representing the PassivHaus Standard amongst others (Pan, 2010; DECLG, 2011). The air tightness standards in Ireland and the UK are less stringent compared with other European countries such as Belgium and Finland (Sinnott and Dyer, 2012; Cornish, 1989; Pan, 2010).

An air permeability of $7 \mathrm{~m}^{3} / \mathrm{h} \cdot \mathrm{m}^{2}$ shall be applied to refurbished dwellings in this study. This is in line with The Energy Savings Trust good practice guidelines and Part L1a Indicative Standard for SAP, 2005 but is lower than the L1a 2010 target and the Energy Savings Trust target for new dwellings of $5 \mathrm{~m}^{3} / \mathrm{h} \cdot \mathrm{m}^{2}$ (EST, 2005; DCLG, 2010). This figure results in a mean $\mathrm{ACH}_{50}$ of 7.35 which Bell and Lowe (2000) have shown to be very achievable and even conservative. This is considered reasonable as air tightness is more difficult to achieve in a refurbishment scenario than for new build as sometimes pipes etc are not accessible.

\section{Model results and analysis}

\subsection{Before thermal retrofit measures}

Table 6 shows the heat loss characteristic of the dwelling in W/ $\mathrm{K}$ and $\mathrm{kWh} / \mathrm{m}^{2}$; as expected, a single storey house has a greater heat loss than a two storey dwelling of the same internal volume due to a greater amount of exposed surface area. There is a high degree of variation with a ratio of standard deviation over the mean (RSD) of $35 \%$ between the dwelling category with the worst 
Table 6

Ranked summary heat loss rate and annual heat energy consumption prethermal retrofit measures by DEAP age band in $\mathrm{W} / \mathrm{K}$ and $\mathrm{kWh} / \mathrm{m}^{2}$.

\begin{tabular}{lcccc}
\hline House type $^{\mathrm{a}}$ & 1SDG & 1SSG & 2SDG & 2SSG \\
\cline { 2 - 5 } & $\mathbf{W} / \mathbf{K}$ & $\mathbf{W} / \mathbf{K}$ & $\mathbf{W} / \mathbf{K}$ & $\mathbf{W} / \mathbf{K}$ \\
\hline E & 834 & 875 & 751 & 792 \\
C & 822 & 862 & 745 & 786 \\
D & 818 & 859 & 736 & 777 \\
A & 800 & 840 & 719 & 760 \\
B & 800 & 840 & 719 & 760 \\
F & 425 & 460 & 439 & 474 \\
I & 410 & 456 & 396 & 442 \\
J & 377 & N/A & 360 & N/A \\
H & 376 & 419 & 365 & 394 \\
G & 371 & 409 & 356 & 394 \\
& & & &
\end{tabular}

House type

\begin{tabular}{llll}
$\mathbf{k W h} / \mathbf{m}^{\mathbf{2}}$ & $\mathbf{k W h} / \mathbf{m}^{\mathbf{2}}$ & $\mathbf{k W h} / \mathbf{m}^{\mathbf{2}}$ & $\mathbf{k W h} / \mathbf{m}^{\mathbf{2}}$ \\
\hline 221 & 232 & 200 & 211 \\
218 & 229 & 197 & 208 \\
217 & 227 & 195 & 206 \\
215 & 226 & 193 & 204 \\
215 & 226 & 193 & 204 \\
107 & 116 & 110 & 119 \\
91 & 100 & 87 & 96 \\
83 & 92 & 80 & 89 \\
81 & 90 & 78 & 66 \\
66 & N/A & 63 & N/A
\end{tabular}

a $1 \mathrm{~S}$ and $2 \mathrm{~S}$ denote single storey or two storey dwellings, respectively; SC and DG denotes single glazing and double glazing, respectively i.e. A1SDG-house type A, single storey, double glazed, J2SSG-house type J, two storey, single glazed.

heat loss characteristic $(E)$ in $\mathrm{W} / \mathrm{K}$ and the dwelling category with the best heat loss characteristic $(G)$.

The positive effect that the Building Regulations have had on the heat loss characteristics, which came into effect in 1979 (in time for DEAP age band $F$ ) is evident from Fig. 3.

The relationship between increasing house size and heat loss is clearly shown with heat loss steadily increasing with time from Age Band $A$ to $E$. It is evident from Table 6 that, for detached dwellings, improvement in $U$-values brought about via the updating of the national Building Regulations over time failed to outweigh the effect of the trend towards increasing floor, window and door areas over time.

Pre-thermal retrofit measures the presence of single glazing on average, results in a $7 \%$ increase in the heat loss $(\mathrm{W} / \mathrm{K})$ for both one and two storey dwellings. A larger percentage return in respect of replacement glazing was expected, however analysis of the results (Table 7) showed that pre thermal improvement measures, the large, thermally poor exposed wall and roof areas account for approximately $63 \%$ of heat loss, thus the heat loss of the glazing is relatively low.

House type $G$ shows a relatively good heat loss characteristic due, in the main, to smaller floor areas with resulting smaller roof and wall areas. It also has a relatively good infiltration rate. Smaller floor areas also have the effect of reducing the thermal bridging coefficient (a function of exposed surface areas).

House types $\mathrm{H}$, I and J have larger window and door areas than house type $G$ which contribute to their relatively high heat loss characteristic, however the model took no account of the requirement for a reduced average $U$-value $\left(U_{\text {ope }}\right)$ relating to larger than average window, door and roof light areas $\left(A_{\text {ope }}\right)$, which is prescribed in the building regulations to account for this phenomenon.

Within housing categories A-E (196,492 houses) the model resulted in an averaged Building Energy Rating (BER) of E2. Heating energy consumption averaged at $212 \mathrm{~kW} \mathrm{~h} / \mathrm{m}^{2}$ with a total average dwelling energy consumption of $344 \mathrm{~kW} \mathrm{~h} / \mathrm{m}^{2}$, corresponding to a heating energy proportion of $62 \%$.

With the newer housing category F-J (210,418 houses) the model resulted in an averaged C2 BER rating. Heating energy consumption for detached housing averaged at $91 \mathrm{~kW} \mathrm{~h} / \mathrm{m}^{2}$ with a total average dwelling energy consumption of $193 \mathrm{~kW} \mathrm{~h} / \mathrm{m}^{2}$, corresponding to a heating energy proportion of $47 \%$.

The average heating energy proportion for all dwelling types is 53\% (SEAI, 2008). Pre thermal retrofit measures the heating energy proportion for house types A-E is significantly higher than the national average which is another indicator of why this housing category has such a high correlation with fuel poverty (Clinch and Healy, 1999).

\subsection{Post thermal retrofit measures}

Fig. 3 shows the scale of energy that can be saved for detached housing in Ireland via the National Insulation programme based on the standard heat loss model. House types A-E (19001077) can potentially realise the greatest savings due to their poor base point.

Referencing Table 8 post thermal retrofit measures, the RSD between the dwelling category with the worst heat loss characteristic in $\mathrm{W} / \mathrm{K}(\mathrm{J})$ and the dwelling category with the best heat loss characteristic (F) is much reduced at $6 \%$ (versus $35 \%$ before measures). House types I and J now exhibit the greatest heat loss in $\mathrm{W} / \mathrm{K}$; the difference is attributed, in the main, to the relatively larger window areas and then to the larger floor and roof areas which have a relatively poor $U$-value.

Referencing Table 8 it can be concluded that, based on the standard heat loss calculation, which ignores solar gains, that as thermal retrofit measures are employed in detached dwellings, the floor $U$-value assumes a much greater relative influence on the overall heat loss characteristic of that dwelling. The thermal bridging and ventilation heat loss coefficients also become more significant. The results indicate that a policy measure designed to reduce $U$-values as areas increase, as in the case of $U_{\text {ope, }}$ is necessary. This measure would be especially significant in single storey detached dwellings due to the relatively large associated envelope areas; envelope areas being a direct function of floor area.

The presence of a high degree of glazing and doors with their relatively poor thermal properties adversely affects the heat loss characteristics of newer housing.

Within housing categories A-E, thermal retrofit measures improve the average dwelling BER from an E2 to a $\mathrm{C} 2 / \mathrm{C} 3$. It was not possible to achieve the desired $\mathrm{C} 1$ category outlined in the reference abatement case of the SEAI 2009 report 'Irelands LowCarbon Opportunity' (SEAI, 2009) without reducing the $U$-value of the floor and further reducing that of the roof. Heat energy consumption averaged at $73 \mathrm{kWh} / \mathrm{m}^{2}$ with a total average dwelling energy consumption of $186 \mathrm{kWh} / \mathrm{m}^{2}$, corresponding to a heating energy proportion of $39 \%$.

Within the newer housing categories F-J thermal retrofit measures improve the average dwelling from a building energy rating from a $\mathrm{C} 2$ to a $\mathrm{C} 1$, heat energy consumption for detached housing averaged at $62 \mathrm{kWh} / \mathrm{m}^{2}$ with a total average dwelling energy consumption of $157 \mathrm{kWh} / \mathrm{m}^{2}$. This corresponds to a heating energy proportion of $40 \%$.

Again, referencing Table 8 post thermal improvement measures; despite house types I and $\mathrm{J}$ being the most recently constructed (post 2000) dwellings; they consume the greatest amount of energy in $\mathrm{kWh} /$ annum than all the older dwellings in this category. However; due to the fact that their relative floor area is so large in respect to the older dwellings in this category, house types I and $\mathrm{J}$ are attributed the best heat energy rating in $\mathrm{kWh} / \mathrm{m}^{2}$ with a BER of $\mathrm{C} 1$ and $\mathrm{B} 3$, respectively. 


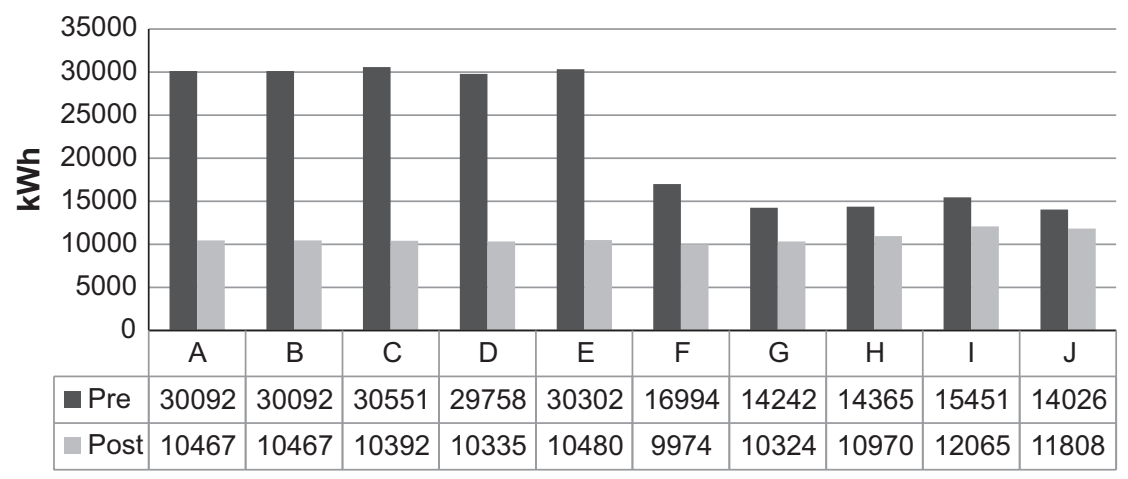

Fig. 3. Average design heat load by DEAP age band-pre and post thermal retrofit measures $(\mathrm{kW} h)$.

Table 7

Heat loss coefficient $(\mathrm{W} / \mathrm{K})$ by element and housing category pre and post thermal retrofit measures.

\begin{tabular}{|c|c|c|c|c|c|c|c|c|}
\hline \multirow[t]{3}{*}{ Element } & \multicolumn{4}{|c|}{ House types A-E (1900 -1977; Pre Bldg. Regs.) } & \multicolumn{4}{|c|}{ House types F-J (1978-2006; Post Bldg. Regs.) } \\
\hline & \multicolumn{2}{|l|}{ Pre } & \multicolumn{2}{|l|}{ Post } & \multicolumn{2}{|l|}{ Pre } & \multicolumn{2}{|l|}{ Post } \\
\hline & Mean & $(\%)$ & Mean & $(\%)$ & Mean & $(\%)$ & Mean & $(\%)$ \\
\hline Thermal bridging coefficient & 39 & 5 & 39 & 14 & 45 & 11 & 45 & 16 \\
\hline Roof & 260 & 32 & 20 & 7 & 49 & 12 & 25 & 9 \\
\hline Doors & 18 & 2 & 18 & 7 & 19 & 5 & 19 & 7 \\
\hline Walls & 246 & 31 & 32 & 12 & 86 & 21 & 35 & 12 \\
\hline Glazing & 95 & 12 & 74 & 23 & 91 & 22 & 64 & 23 \\
\hline Floor & 55 & 7 & 55 & 20 & 41 & 10 & 41 & 14 \\
\hline Ventilation heat loss coefficient & 83 & 11 & 45 & 17 & 77 & 19 & 53 & 19 \\
\hline Total heat loss coeefficient & 796 & 100 & 283 & 100 & 408 & 100 & 282 & 100 \\
\hline
\end{tabular}

Table 8

Ranked summary heat loss rate post thermal retrofit measures by DEAP age band in $\mathrm{W} / \mathrm{K}$ and $\mathrm{kWh} / \mathrm{m}^{2}$.

\begin{tabular}{|c|c|c|c|c|}
\hline \multirow[t]{2}{*}{ House type $^{a}$} & $1 \mathrm{SDG}$ & $1 \mathrm{SSG}->1 \mathrm{SDG}$ & $2 S D G$ & $2 S S G->2 S D G$ \\
\hline & $\mathbf{W} / \mathbf{K}$ & $\mathbf{W} / \mathbf{K}$ & $\mathbf{W} / \mathbf{K}$ & $\mathbf{W} / \mathbf{K}$ \\
\hline $\mathrm{J}$ & 333 & $\mathrm{~N} / \mathrm{A}$ & 292 & $\mathrm{~N} / \mathrm{A}$ \\
\hline I & 331 & 307 & 296 & 272 \\
\hline $\mathrm{H}$ & 305 & 282 & 274 & 251 \\
\hline $\mathrm{E}$ & 304 & 282 & 271 & 249 \\
\hline $\mathrm{D}$ & 299 & 277 & 267 & 245 \\
\hline C & 298 & 276 & 265 & 244 \\
\hline A & 297 & 276 & 265 & 243 \\
\hline B & 297 & 276 & 265 & 243 \\
\hline G & 293 & 273 & 262 & 242 \\
\hline $\mathrm{F}$ & 286 & 267 & 256 & 237 \\
\hline \multicolumn{5}{|l|}{ House type } \\
\hline & $\mathbf{k W h} / \mathbf{m}^{2}$ & $\mathbf{k W h} / \mathbf{m}^{2}$ & $\mathbf{k W h} / \mathbf{m}^{2}$ & $\mathbf{k W h} / \mathbf{m}^{2}$ \\
\hline C & 80 & 74 & 71 & 66 \\
\hline B & 80 & 74 & 71 & 65 \\
\hline A & 80 & 74 & 71 & 65 \\
\hline $\mathrm{D}$ & 80 & 74 & 71 & 65 \\
\hline E & 79 & 73 & 70 & 65 \\
\hline $\mathrm{F}$ & 72 & 67 & 64 & 60 \\
\hline G & 72 & 67 & 64 & 59 \\
\hline $\mathrm{H}$ & 67 & 62 & 60 & 55 \\
\hline I & 65 & 60 & 58 & 54 \\
\hline $\mathrm{J}$ & 58 & $\mathrm{~N} / \mathrm{A}$ & 51 & N/A \\
\hline
\end{tabular}

a $1 \mathrm{~S}$ and $2 \mathrm{~S}$ denote single storey or two storey dwellings, respectively; SG and DG denotes single glazing and double glazing, respectively i.e. A1SDG-house type A, single storey, double glazed, J2SSG-house type J, two storey, single glazed.

Referencing Fig. 4; Over the period $1900-2006$, when $\mathrm{kWh} / \mathrm{m}^{2}$ is plotted by DEAP age band the trend shows a significant overall decrease with time (RSD_ $8 \%$ ) suggesting a pattern of reduction in energy consumption with time; however the same graph shows the

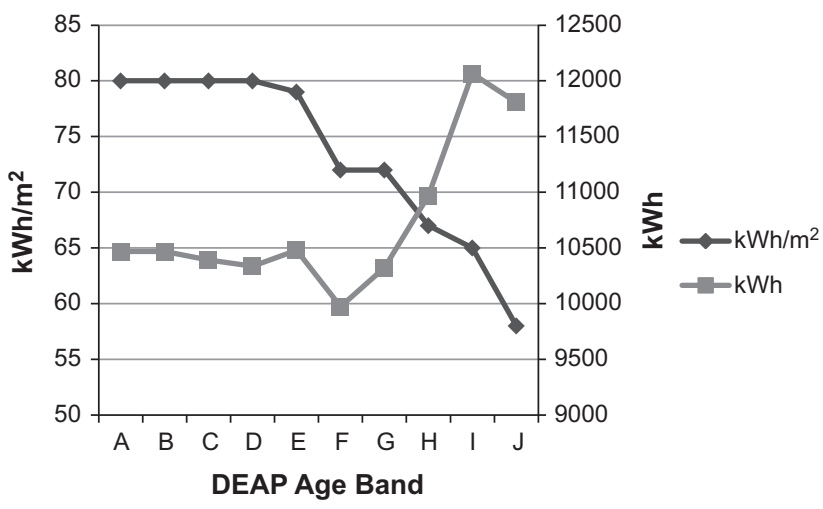

Fig. 4. The trend in heat energy consumption by DEAP age band post thermal improvement measures, expressed in terms of $\mathrm{kW} \mathrm{h} / \mathrm{m}^{2}$ and $\mathrm{kWh}$.

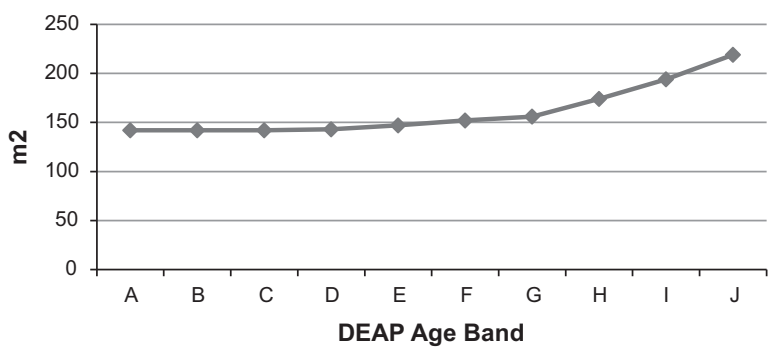

Fig. 5. The trend in floor area for detached dwellings by DEAP age band.

total energy consumption in $\mathrm{kWh}$ showing an overall increase (RSD-5\%) over the same period. The apparent contradiction is explained by the steady and more rapid growth in the floor area of dwellings over time (RSD-16\%); see Fig. 5. 


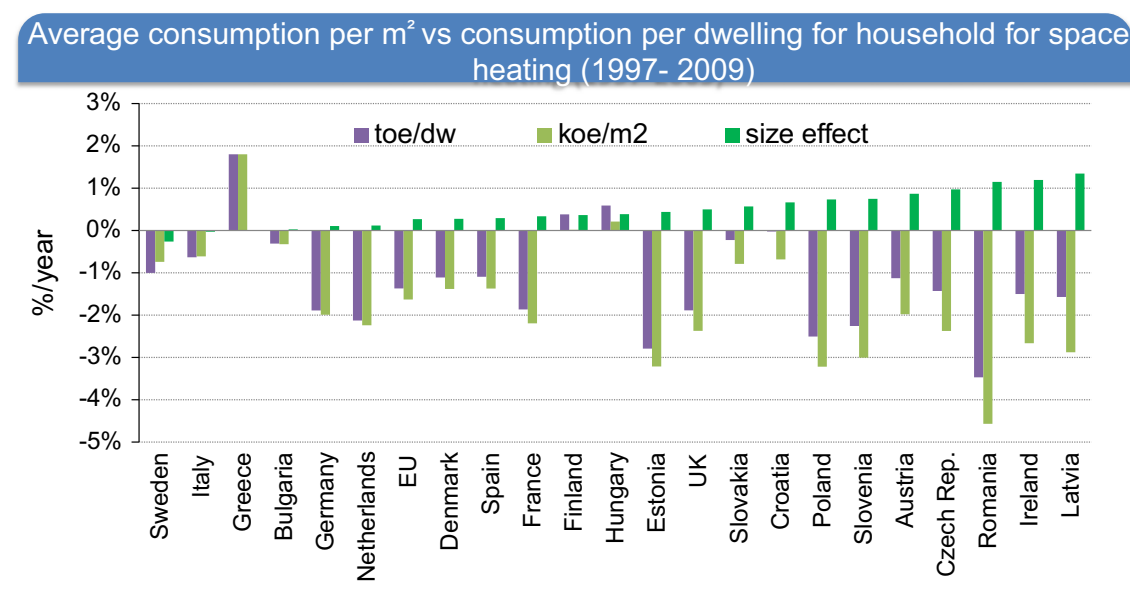

Fig. 6. Heating energy use per dwelling, per $\mathrm{m}^{2}$ and size effect (1997-2009)*.

"1997-2008 for Spain, Slovenia and Romania, floor area of Irish dwellings increases by 1.2\%/annum from 1997 to 2009.

Source: Odyssee.

Table 9

Model results: potential cost and carbon savings and payback by DEAP age band.

\begin{tabular}{|c|c|c|c|c|c|c|c|c|c|c|c|c|c|}
\hline \multirow[t]{2}{*}{ DEAP age band } & \multirow[t]{2}{*}{ Amt. of houses in category } & \multicolumn{3}{|c|}{$\operatorname{Cost}^{\mathrm{b}}(\mathrm{m} €)$} & \multicolumn{3}{|c|}{$\mathrm{CO}_{2}^{\mathrm{a}}\left(\mathrm{MtCO}_{2}\right)$} & \multirow{2}{*}{\multicolumn{2}{|c|}{ (\%) Reduction }} & \multirow{2}{*}{\multicolumn{2}{|c|}{ (\%) Saving by category }} & \multirow{2}{*}{\multicolumn{2}{|c|}{ Average payback period ${ }^{\mathrm{C}}$}} \\
\hline & & Pre & Post & Saving & Pre & Post & Saving & & & & & & \\
\hline A & 44785 & 79.6 & 29.1 & 50.5 & 0.352 & 0.127 & 0.225 & 64 & $65 \%$ & 19 & $82 \%$ & 12 & $12 \mathrm{yrs}$ \\
\hline B & 34552 & 61.4 & 21.4 & 40.0 & 0.267 & 0.094 & 0.173 & 65 & & 14 & & 12 & \\
\hline C & 32454 & 58.5 & 19.9 & 38.6 & 0.255 & 0.087 & 0.168 & 66 & & 14 & & 11 & \\
\hline $\mathrm{D}$ & 32244 & 56.6 & 19.7 & 37.0 & 0.247 & 0.086 & 0.161 & 65 & & 13 & & 12 & \\
\hline E & 52457 & 93.8 & 32.5 & 61.3 & 0.409 & 0.141 & 0.268 & 66 & & 22 & & 11 & \\
\hline $\mathrm{F}$ & 29817 & 29.9 & 17.6 & 12.3 & 0.13 & 0.076 & 0.054 & 42 & $26 \%$ & 4 & $18 \%$ & 24 & 33 yrs \\
\hline G & 60233 & 50.6 & 36.7 & 13.9 & 0.22 & 0.16 & 0.06 & 27 & & 5 & & 30 & \\
\hline $\mathrm{H}$ & 45694 & 38.7 & 29.6 & 9.1 & 0.169 & 0.129 & 0.04 & 24 & & 3 & & 35 & \\
\hline I & 52764 & 48.1 & 37.6 & 10.5 & 0.21 & 0.164 & 0.046 & 22 & & 4 & & 33 & \\
\hline \multirow[t]{2}{*}{$\mathrm{J}$} & 21910 & 18.1 & 15.3 & 2.8 & 0.079 & 0.067 & 0.012 & 15 & & 1 & & 45 & \\
\hline & 406910 & 535 & 259 & 276 & 2.34 & 1.13 & 1.21 & 45 & 100 & 100 & $100 \%$ & 23 & \\
\hline
\end{tabular}

a Oil boiler fired on kerosene with a calorific value of $37,201 \mathrm{~kJ} / \mathrm{l}$ and an efficiency of $80 \% \mathrm{CO}_{2}$; emissions for kerosene-0.257004 kgCO $/ 2 \mathrm{~kW}$ h Oil (EPA 2008 ).

${ }^{b}$ Cost of oil $€ 0.61 / 1000$ litre oil fill.

c Price of oil inflated $4.52 \%$ annually.

This phenomenon also applies at EU level where between 1997 and 2009 " $20 \%$ of energy efficiency progress for thermal uses has been offset, all things being equal, by the fact that dwellings are becoming larger" (Lapillonne et al., 2012). Lapillonne et al. (2012) refer to this phenomenon as the 'size effect'. The size effect for Irish dwellings is particularly pronounced with a growth in dwelling floor area of $1.3 \%$ per annum between 1997 and 2007 (total 13\%) (Dennehy et al., 2009) versus $0.25 \%$ per annum (total $3 \%$ ) for the same period at EU level (Lapillonne et al., 2012). Referencing Fig. 6, if 1.2\% growth in floor areas between 1997 and 2009 (total 14.4\%) is assumed for Irish dwellings in general around $75 \%$ of the overall reduction in energy consumption gained in tonnes of oil equivalent per dwelling (toe/dw) through energy efficiency measures has been offset by the so called size effect. The size effect is therefore analogous to increasing indoor design temperatures which shall have a similar effect on overall energy use by eroding energy efficiency gains. The size effect for detached dwellings in Ireland is especially pronounced with a growth in floor area of 2.9\% per annum between 1997 and 2006 (26\% in total) offsetting all energy efficiency gains achieved within this housing category.
In this regard the authors are critical of the energy performance assessment methods adopted in the Irish Building Regulations for dwellings. The regulations require designers to calculate compliance using DEAP; the primary energy consumption figure in $\mathrm{kWh} / \mathrm{m}^{2} / \mathrm{yr}$ of the proposed dwelling is calculated and this figure is divided by that of the primary energy consumption of a reference dwelling, resulting in the energy performance coefficient (EPC). In order to demonstrate that an acceptable primary energy consumption rate has been achieved, the calculated EPC of the dwelling being assessed should be no greater that the maximum permitted energy performance coefficient (MPEPC), the MPEPC is currently 0.6 (DECLG, 2011). Whilst the reduction in the MPEPC from 1 in the 2007 regulations to 0.6 in the 2011 regulations is welcome, the calculation uses the same floor area for the reference dwelling as that of the actual dwelling; therefore this method of calculating energy efficiency does not militate against the size effect phenomenon and effect an actual reduction in the annual energy use of the dwelling. Therefore, using the same rationale adopted in the building regulations of reducing $U_{\text {ope }}$ in line with increasing $A_{\text {ope, }}$ this study recommends that the Building Regulations look to area-weighting the maximum average $U$-value $\left(U_{\mathrm{m}}\right)$ by reducing this value in line with increasing building floor area $\left(A_{\mathrm{f}}\right)$. 
Table 10

Cost of thermal retrofit measures by element.

\begin{tabular}{|c|c|c|c|c|c|c|c|c|}
\hline & \multicolumn{2}{|l|}{$1 \mathrm{SDG}$} & \multicolumn{2}{|l|}{$1 S S G$} & \multicolumn{2}{|l|}{ 2SDG } & \multicolumn{2}{|l|}{ 2SSG } \\
\hline & Mean & $(\%)$ & Mean & $(\%)$ & Mean & $(\%)$ & Mean & $(\%)$ \\
\hline \multicolumn{9}{|c|}{ House types A-E (1900 -1977; Pre Bldg. Regs.) } \\
\hline Glazing & 0 & 0 & 3600 & 22 & 0 & 0 & 3600 & 18 \\
\hline Walls & 9760 & 78 & 9760 & 61 & 14800 & 90 & 14800 & 74 \\
\hline Roof & 2259 & 18 & 2259 & 14 & 1131 & 7 & 1131 & 6 \\
\hline \multirow[t]{2}{*}{ Air tightness } & 500 & 4 & 500 & 3 & 500 & 3 & 500 & 2 \\
\hline & $€ 12,519$ & 100 & $€ 16,119$ & 100 & $€ 16,431$ & 100 & $€ 20,031$ & 100 \\
\hline \multicolumn{9}{|c|}{ House types F-J (1978 -2006; Post Bldg. Regs.) } \\
\hline Glazing & 0 & 0 & 3563 & 20 & 0 & 0 & 3563 & 18 \\
\hline Walls & 11080 & 77 & 10850 & 62 & 16720 & 90 & 16350 & 74 \\
\hline Roof & 2823 & 20 & 2666 & 15 & 1410 & 7 & 1331 & 6 \\
\hline \multirow[t]{2}{*}{ Air tightness } & 500 & 3 & 500 & 3 & 500 & 3 & 500 & 2 \\
\hline & $€ 14,403$ & 100 & $€ \mathbf{1 7 , 5 7 9}$ & 100 & $€ 18,630$ & 100 & $€ 21,744$ & 100 \\
\hline
\end{tabular}

\subsection{Economic and carbon analysis}

Table 9 outlines the running costs and potential savings resulting from the model by DEAP Age Band.

The total spend on energy in the residential sector in 2006 was $€ 2.5$ billion and the average spend on energy per permanently occupied dwelling in 2006 was $€ 1767^{3}$. If we apply the average heat energy proportion of 53\% to this figure the average spend on heating Irish homes is $€ 937$ (SEAI, 2008).

The model results in an average heating running cost of approximately $€ 1792$ for house types A-E (1900-1977) which is an increase of $92 \%$ on the national average and $€ 919$ for house types F-J (1978-2006) which approximates the national average.

The values produced by the model are high as it is assumed that the dwelling is heated to a constant temperature of $20^{\circ} \mathrm{C}$, in all weather conditions up to a balance temperature of $15^{\circ} \mathrm{C}$; and solar gains are ignored. However the percentage reduction achievable through the energy efficiency upgrades in line with NEAPP policies is representative.

Table 9 shows that at current oil prices and emission rates, for every euro saved in running costs arising from the thermal retrofit measures a saving of $4.35 \mathrm{kgCO}_{2} / €$ results.

The model predicts a reduction of $65 \%$ in running costs and $\mathrm{CO}_{2}$ emissions for house types $\mathrm{A}-\mathrm{E}$ and a reduction of $26 \%$ in running costs and $\mathrm{CO}_{2}$ emissions for house types $\mathrm{F}-\mathrm{J}$ from retrofit measures, and forecasts a total saving of 276 million euro and a $\mathrm{CO}_{2}$ abatement of $1.21 \mathrm{MtCO}_{2}$. By applying the base vacancy rate of $15 \%$ annual savings of $€ 235$ million and $1.03 \mathrm{MtCO}_{2}$ result.

There is evidence of savings take-back when houses are thermally retrofitted (Lomas, 2010, SEAI, 2008, Clinch and Healy, 2003, 1999). In 2004 it was found that $12.7 \%$ of Irish households have some difficulties (intermittent) in heating their homes, $4.7 \%$ were chronically fuel poor with $17.4 \%$ being totally fuel poor (Clinch and Healy, 2004, Clinch et al., 2001). If we assume that all the savings, for chronically and totally fuel poor houses, go towards alleviating fuel poverty and there is no reduction in fuel consumption from the thermal retrofit measures, then potential savings can be discounted by $22.1 \%(4.7 \%+17.4 \%)$. This will result in estimated cost savings of $€ 183$ million and a corresponding reduction of $0.80 \mathrm{MtCO}_{2}$.

The SEAI (2009) report 'Irelands Low-Carbon Opportunity' estimates a total national residential carbon abatement potential of $1.84 \mathrm{MtCO}_{2}$ by 2030 through incrementally upgrading dwellings to a C1 BER. This study suggests that thermally retrofitting

\footnotetext{
${ }^{3}$ Provisional data from 2008 indicated an average non-inflation adjusted bill of approximately $€ 2,200$ (Curtain, 2009).
}

the detached housing stock alone can contribute $44 \%$ of this target abatement figure; with the vast majority ( $82 \%$ corresponding to $36 \%$ of the national total) of this from housing categories A-E. Policy measures should therefore concentrate on detached housing constructed prior to the implementation of the building regulations.

\subsection{Payback analysis}

The cost of retrofitting external insulation varies widely depending on a number of variables. The most important being the surface area of the house, depth of insulation and maturity of the market. Assuming a depth of $150 \mathrm{~mm}$, the installed cost in Ireland in 2009 was approximately $€ 100 / \mathrm{m}^{2}$. This figure compares unfavourably with countries such as Germany where the market has been given the opportunity to mature and where competition between contractors has emerged. The average price of external wall insulation in Germany, where labour costs would be comparable to Ireland is in the region of $€ 60 / \mathrm{m}^{2}$. Prices therefore would be expected to fall significantly as the market matures, scale is achieved and increased competition emerges. The model budgets for a price of $€ 100 / \mathrm{m}^{2}$ for retrofitting external wall insulation thus ensuring conservative estimates on the payback (Curtain, 2009).

To establish the cost, of replacing single with double glazing, open market prices were sought. In 2010, the approximate installed price of white PVC was $€ 133 / \mathrm{m}^{2}$ and colour PVC was $€ 150 / \mathrm{m}^{2}$. Timber and aluminium windows were more expensive at $€ 245 / \mathrm{m}^{2}$ and $€ 299 / \mathrm{m}^{2}$, respectively. Colour PVC at an installed cost of $€ 150 / \mathrm{m}^{2}$ was assumed in the calculation (BMQS, 2011).

Retrofitting additional roof insulation was budgeted at $€ 15 / \mathrm{m}^{2}$. This figure is relatively low due to the economy of scale gained from the larger than average roof areas associated with detached housing. Achieving a greater level of air tightness was assumed to cost $€ 500$ (Montague, 2011).

Table 9 details calculated payback periods achieved for the retrofit measures. For house types A-E the average payback period is approximately 12 years and for house types F-J the average payback is approximately 33 years. Table 10 details retrofit costs by element for the various house types, the average estimated refurbishment costs are $€ 16,379 /$ dwelling. Table 10 shows that retrofitting wall insulation is by far the most costly measure due to relatively large wall areas. For this reason two storey dwellings are more costly to retrofit than single storey dwellings. Air tightness is a low cost retrofit measure that has a high impact. The estimated total cost of refurbishment cost for house types $\mathrm{A}-\mathrm{E}$ and $\mathrm{F}-\mathrm{J}$ is $€ 3.2$ billion and $€ 3.6$ billion, respectively. 


\section{Government Policy Measures}

Research has shown that the majority of abatement opportunities are cost negative (SEAI, 2009). However if the cost and $\mathrm{CO}_{2}$ measures are to be realised it is important that the public at large, which includes landlords, engage with the policy measures the government has implemented, but the hard truth is that in recessionary times, money is an issue (Cillo and Lachman, 1999; Bernier et al., 2010).

"Lack of money (or competing demands for available funds), lack of technical expertise, and uncertainty about one's continued occupancy at a particular location all combine to prevent customers from choosing to invest in energy efficiency in their homes and businesses" (Cillo and Lachman, 1999).

The findings of Cillo and Lachman in their 1999 paper are supported by research carried out in Ireland in 2009 by Amárach Research wherein it was found that $58 \%$ of homeowners responsible for energy bills said they did not have enough money saved to upgrade their home, whilst $29 \%$ said they did not know which upgrade measures their homes needed. The research also stated that $43 \%$ had made energy efficiency improvements and were keen to do more, $28 \%$ had considered, but had not carried out, improvements, whilst $16 \%$ had not considered an energy upgrade before (Colley, 2010).

"The results indicate that Irish people are ready to invest in energy efficiency if the requirement for upfront finance is removed," (Colley, 2010)

If society is to realise the benefits of energy efficiency upgrades, financial obstacles of this nature must be overcome if any significant volume of energy efficiency work is to be realised.

The market based Pay-As-You-Save (PAYS) approach to energy efficiency investment offers people the opportunity to upgrade the energy efficiency of the building they occupy without requiring them to provide upfront finance and without placing debt obligation on them. A PAYS tariff is instead assigned to the building through a utility bill. Customers who sign up for the PAYS tariff see an immediate financial benefit, as the repayment tariff is set up to amount to less than the energy savings that the customer makes. Such a system, known as the 'Green Deal', which contains the Golden Rule that "The expected financial savings must be equal to or greater than the costs attached to the energy bill" was expected to commence in the UK in Autumn 2012 (DECC, 2010). Customers could even use such a tariff to make incremental improvements over time. PAYS therefore promises the prospect of creating a continuous demand for innovative technologies to meet customers' needs in a changing energy landscape (Cillo and Lachman, 2001; Colley, 2010; Curtain, 2009; Bernier et al., 2010).

In 2006, the International Energy Agency (IEA) recommended a range of policy instruments to encourage greater energy efficiency in the residential and services sectors including;

"The creation of incentives for energy utilities to implement or promote certified energy-saving measures among their client base, or the imposition of obligations on them to do so"

\section{(IEA, 2006).}

There is precedent in Ireland for this type of scheme. In the aftermath of the 1979 oil crisis, ESB and Moy Insulation teamed up to offer attic insulation to customers, requiring no upfront capital investment, but instead adding the cost to the energy bills of the participating customers. This scheme was deemed to be a commercial success and by 2004, $80 \%$ of Irish homes were so equipped (Colley, 2010; Clinch and Healy, 2004).
The Irish Government's Department of Communications, Energy and Natural Resources has recently gone out to consultation on a programme that could encourage the energy supply sector to adapt their business models to incorporate PAYS. The department is proposing that the programme, to be called the Energy Demand Reduction Target (EDRT) (DCENR, 2010) shall have a particular focus on stimulating end-use efficiency and may involve passing a law forcing the energy supply sector to substantially reduce the amount of energy consumed in Ireland.

There is a considerable role for the government in such a scheme as longer term PAYS investments (such as external wall insulation retrofit) could arguably place a disproportionate risk (debt) on utility companies that the government would need to underwrite, possibly through the establishment of a green bank or through the issue of green bonds. Furthermore, the government and state agencies would have a key role in marketing, monitoring and regulating such a scheme and perhaps designing appropriate financing arrangements. Curtain in a 2009 study found that the overall cost to the state of administering a PAYS scheme would be recouped many times over in terms of carbon credits alone and states that "this is before ancillary employment, energy savings, health, morbidity and political benefits are considered", Curtain (2009) goes on to state that the state's fuel poverty mitigation bill comes to approximately $€ 400$ million per annum.

\section{Limitations of this study}

- The heat loss calculation outlined in BS EN 12831:2003 Heating Systems in buildings is a steady state heat loss calculation meaning heat gains are not included. This will lead to an overestimation of the energy saving potential of the thermal retrofit measures because heat gains as a result of solar penetration into the dwelling will reduce the heating energy requirement. Notwithstanding the above, the results of this study were compared with a sample set of base geometries modelled in DEAP (which accounts for solar gain) and results correlated well. The general trends resulting from this study give an insight into the scale of cost savings achievable.

- The calculation does not account for the significant effect of user habits in the operation of a heating system (Firth et al., 2009; Shipworth et al., 2010; Guerra-Santin and Itard, 2010; Gram-Hanssen, 2010). For example, it is considered unlikely that a household will turn on the heating for an hour in June for a 1 degree temperature difference; however, it is necessary to allow this to ensure the model was working within defined parameters.

- It is assumed that the entire dwelling, meaning all rooms, is heated for the duration of defined occupancy period to a fixed internal temperature. This is unlikely due to operating costs. However it is known that after insulation is installed dwelling occupants may heat more of their house, and to a higher temperature (Lomas, 2010).

- Type of Tenure is ignored, $21 \%$ of dwellings in Ireland are occupied by tenants. Landlords who, by and large, do not pay the energy costs of heating are not motivated to invest in the energy efficiency of the property, while tenants who pay the bill are not motivated to invest in the fabric of a building they do not own (Curtain, 2009; Scott et al., 2008). However detached housing suffers less from this phenomenon, than other dwelling types, as they have the highest degree of owner occupation.

- This study has not taken into account the quality of retrofit work.

- The model took no account of the requirement for a reduced average $U$-value $\left(U_{\text {ope }}\right)$ relating to a larger than average 
window, door and roof light areas $\left(A_{\text {ope }}\right)$ described in the building regulations.

- Referencing Section 2.2; the model used average figures for infiltration rates from the BRE database $\left(\mathrm{ACH}_{50}\right)$ for both single and two storey dwellings. $\mathrm{CIBSE} \mathrm{ACH}_{50}$ divisors were used to convert these figures to $\mathrm{ACH}$ the result is a higher permeability for two storey dwellings over one storey which is misrepresentative, future air permeability studies should quantify whether the tested dwelling is single storey or two storeys.

\section{Areas for future study}

- Another national survey on housing quality should be carried out as the information currently available is outdated. In addition to the survey questions originally asked, the study should establish typical occupancy profiles for domestic units along with habits of heating use. Thus allowing for energy efficiency measures to be accurately quantified with respect to prevailing outdoor weather conditions. The study should also quantify the amount of glazing and its orientation to allow for dynamic simulation of the building conditions. DEAP age bands should be used to categorise the results.

- Pre-refurbishment monitoring and feedback for case study dwellings is necessary. This ensures there is a robust learning process in place for the design team, owners (landlords) and occupants, which is carried out through post-implementation evaluation. This approach establishes feedback loops for comparing expectations with outcomes, enabling assessment of the effectiveness of the low-carbon interventions (Gupta and Chandiwala, 2010).

- More statistical weather files need to be established for rural Ireland.

- With regard to energy efficiency upgrades

"Energy demand targets and utility targets perhaps provide the most promise particularly in the context of budget constraints. A comprehensive solution would require elements of regulation and grant aid. Further analysis of costs and benefits associated with these options and detailed research into how they might be financed is urgently required if the opportunities are to be effectively captured"

(Curtain, 2009).

- A database of air tightness of Irish Housing by DEAP age band, house type and number of storeys is required.

- Further study is required to establish a thermal policy measure which looks to area weighting the maximum average U-value (Um) by reducing $\mathrm{Um}$ in line with increasing building floor area (Af).

\section{Conclusions}

The case for energy efficiency measures is categorical; the potential exists to reduce running costs and $\mathrm{CO}_{2}$ emissions by an average of $63 \%$ for housing constructed prior to the 1979 building regulations (house types $\mathrm{A}-\mathrm{E}$ ) and by $26 \%$ for newer housing.

The ratio of amounts of $\mathrm{CO}_{2}$ which can be potentially saved to the amount of money saved was calculated as $4.35 \mathrm{kgCO}_{2} / €$. Nationally an annual saving of $€ 183$ million euro is theoretically achievable with a resultant saving of $0.80 \mathrm{MtCO}_{2}$ arising from insulation retrofits, the replacement of single glazed windows and increasing air tightness.

The greatest savings (82\%) or $€ 150 \mathrm{~m}$ and $0.66 \mathrm{MtCO}_{2}$ are achieved by addressing the pre building regulation housing stock. Pre 1940 dwellings are normally without a cavity or an existing filled cavity will require either internal or external insulation. Dwellings constructed between 1940 and 1970 were normally constructed with cavity walls will provide the shortest payback as they are more easily retrofitted with insulation blown into the cavity. This is positive as houses built between 1941 and 1979 demonstrate the highest level of persistent fuel poverty and would benefit most from fitting cavity wall insulation (Clinch and Healy, 2004).

As thermal retrofit measures are employed within the existing stock and the thermal properties of the dwellings become more uniform, the floor area is ultimately the most influential factor on the heat loss characteristic of a dwelling as large floor areas result in increased building envelope surface areas which correlate with an increased level of glazing, increased levels of thermal bridging, increased ventilation loss due to larger volumes and presumably more bathrooms and thus penetrations to the exterior.

While the thermal characteristics of the buildings improve with time and energy use per $\mathrm{m}^{2}$ is decreasing, the majority of energy efficiency progress for thermal use in Irish dwellings is being offset, all things being equal, by the fact that dwellings have become larger. In order to militate against the size effect, this study recommends a policy measure which looks to areaweighting the maximum average $U$-value $\left(U_{\mathrm{m}}\right)$ by reducing $U_{\mathrm{m}}$ in line with increasing building floor area $\left(A_{\mathrm{f}}\right)$.

Under the thermal retrofit measures employed in the model it was not possible for house types A-E to achieve the desired C1 category outlined in the reference abatement case of the SEAI, 2009 report 'Irelands Low-Carbon Opportunity' (SEAI, 2009) without reducing the $U$-values of the floors and further reducing that of the roofs. Irish homes have a low penetration of floor insulation. Homeowners would need to be incentivised to insulate floors possibly by introducing a greater grant allocation for this measure.

As insulation levels improve, the significance of ventilation heat loss is greater. There is significant scope for improvement in the air tightness of Irish dwellings, old and new. Irish dwellings are on average much more leaky that dwellings in many other countries, notably in Canada and Scandinavia. Cavity masonry construction exhibits the worst air tightness characteristics (Stephen, 1998). As part of retrofit measures, air tightness needs to be considered.

External wall insulation is the most costly thermal retrofit measure but shall become more cost effective as the market matures.

Research has shown that, at state level, the majority of carbon abatement opportunities are cost negative. However the costs of energy efficiency retrofit measures are significant and possibly prohibitive for the end-user. The Irish state needs to adopt an active role in alleviating the financial obstacles faced by society at large if meaningful energy efficiency measures are to be realised in the Irish housing stock.

\section{References}

Beddington, J., 2008. Managing energy in the built environment: rethinking the system. Energy Policy 36, 4299-4300.

Begley, D.E. 2011. Fuel debt: the older population. Energy Action Conference: Fue Poverty. Age Action Ireland.

Bell, M., Lowe, R., 2000. Energy efficient modernisation of housing: a UK case study. Energy and Buildings 32, 267-280.

Bernier, P.F.,.R.A., Ainger, C., et al., 2010. Assessing the sustainability merits of retrofitting existing homes. Proceedings of the Institution of Civil Engineers-Engineering Sustainability 163, 1970207.

BMQS. 2011. RE: Cost of New Windows to Existing House. Type to AHERN, C.

Brophy, V.C., J.P., Convery, F., Healy, J., King, C., Lewis 0. 1999. Homes for the 21st Century: Energy Action.

Cillo, P.A., Lachman, H., 1999. Pay-as-you-Save Energy Efficiency Products: Restructuring Energy Efficiency. The Energy Efficiency Institute, Inc. 
Cillo, P.A., Lachman, H., 2001. More Distributed Generation with Pay-As-You-Save. Energy Efficiency Institute, Inc, US

Clinch, J.P., Healy, J.D., 2000. Domestic energy efficiency in Ireland: correcting market failure. Energy Policy 28, 1-8.

Clinch, J.P., Healy, J.D., 1999. Alleviating fuel poverty in Ireland, a program for the 21st century. International Journal of Housing Science 23, 203-215.

Clinch, J.P., Healy, J.D., 2003. Valuing improvements in comfort from domestic energy-efficiency retrofits using a trade-off simulation model. Energy Economics 25, 565-583.

Clinch, J.P., Healy, J.D., 2004. Quantifying the severity of fuel poverty, its relationship with poor housing and reasons for non-investment in energy-saving measures in Ireland. Energy Policy, 207-220.

Clinch, J.P., Healy, J.D., King, C., 2001. Modelling improvements in domestic energy efficiency. Environmental Modelling and Software 16, 87-106.

Colley, J., 2010. Pay As You Save Campaign. Construct Ireland 4.

Cornish, J. 1989. Improving the Habitability of Large Panel System Dwellings. In: Report, B. (Ed.) BR 164. Garston.

CSO 2011. Census of Population 2011_Preliminary Results. Dublin.

Curtain, J. 2009. Jobs, Growth and Reduced Energy Costs: Greenprint for a National Energy Efficiency Retrofit Programme. Dublin, Ireland: The Institution of International and European Affairs.

DCENR 2010. Energy Demand Reduction Target (EDRT) Programme Consultantion Paper. In: Department of Communications, E. A. N. R. (Ed.). Dublin.

DCLG 2010. Building Regulations. Conservation of Fuel and Power. London: Office of the Deputy Prime Minister, HM Government.

DECC 2010. The Green Deal: A Summary of the Government's Proposals. In: Change, D. O. E. A. C. (Ed.). 5.

DECLG 2011. Conservation of Fuel and Energy in Dwellings. Building RegulationsTechnical Guidance Document L. The Stationery Office, Dublin, Ireland: The Irish Government.

Dennehy, E., Howley, M., O'Gallachoir, D.B., 2009. Energy efficiency policies an measures in Ireland. In: Project, O.-M. (Ed.), Monitoring of Energy Efficiency in EU 27. Sustainable Energy Ireland, Norway and Croatia. Cork, Ireland.

Energy_Action. 17th May 2011 2010. RE: SEAI Pilot Scheme-External Wall Insulation. Type to AHERN, C.

EST 2005. Improving Airtightness in Dwellings. In: TRUST, E. S. (Ed.) GPG 224.

Etheridge, D.W., Nevrala, D.J. \& Stanway, R.J. 1987. Ventilation in Traditional and Modern Housing. Presented at 53rd Autumn Meeting. London: Research and Development Division, British Gas plc.

Federcasa, I.H.F. 2006. Housing Statistics in the European Union 2005/2006. In: Federation, M. O. I. O. T. I. R. F. I. H. (Ed.). Rome.

Firth, S.K., Loams, K.J., Wright, A.J., 2009. Targeting household energy-efficiency measures using sensitivity analysis. Building Research and Information 38 , 25-41.

Fitzgerald, J., 2005. The Irish housing stock: growth in number of vacant dwellings. In: ESRI (Ed.), Quarterly Economic Commentary. Spring ed, Dublin.

Gram-Hanssen, K., 2010. Residential heat comfort practices: understanding users. Building Research and Information 38, 175-186.
Guerra-Santin, O., Itard, L., 2010. Occupants' behavious:determinants and effects on residential heating consumption. Building Research and Information 38, 318-338.

Gupta, R., 2009. Moving towards low-carbon buildings and cities: experiences from Oxford, UK. International Journal of Low-Carbon Technologies 4, 159-168.

Gupta, R., Chandiwala, S., 2010. Understanding occupants: feedback techniques for large scale low-carbon domestic refurbishements. Building Research and Information 38, 530-548.

Gupta, R.A.C.S., 2010. Understanding occupants: feedback techniques for large scale low-carbon domestic refurbishements. Building Research and Information 38, 530-548.

IEA, 2006. World Energy Outlook. Internal Energy Agency, Paris, France.

Johnston, D.D., Miles-Shenton, D. Bell, P.M \& Wingfield, DJ. 2011. Airtightness of Buildings-Towards Higher Performance. In: Centre for the Built Environment, L. M. U. (Ed.). London.

Kitchen, R.N., Gleeson, J.N., Keaveney, K.Q. \& O'Callaghan, C.N. 2010. A Haunted Landscape: Housing and Ghost Estates in Post-Celtic Tiger Ireland. NIRSA Working Paper Series [Online], 59. Available: <http://eprints.nuim.ie/2236/1/ WP59-A-Haunted-Landscape.pdf $>$.

Lapillonne, B., Sebi, C. \& Pollier, K. 2012. Energy Efficiency Trends for Households in the EU. Enerdata-An Analysis Based on the ODYSSEE Database.

Lomas, K.J., 2010. Carbon reduction in existing buildings:a trandisciplimary approach. Building Research and Information 38, 1-11.

Montague, C.. 1st November 2011 2011. RE: Achieving Domestic Airtightness. Type to AHERN, $C$

Pan, W., 2010. Relationships between air-tightness and its influencing factors of post-2006 new-build dwellings in the UK. Building and Environment 45, 2387-2399.

SAP 2005. The (UK) Government's Standard Assessment Procedure for Energy Rating of Dwellings. In: DEFRA (Ed.). Garston, Watford: Published on Behalf of DEFRA by: Building Reseach Establishment.

Scott, S., Sean, L., Claire, K., Donal, M. \& Tol, R.S.J. 2008. Fuel Poverty in Ireland: Extent, Affected Groups and Policy Issues. Working Paper No.262. ESRI.

SEAI 2008. Energy in the Residential Sector. In: IRELAND, S. E. (Ed.). Dublin.

SEAI 2009. Ireland's Low-Carbon Opportunity -An Analysis of the Costs and Benefits of Reducing Greenhouse Gas Emissions In: Motherway, D. B., Walker, D. N. \& CO, A. C. O. B. M. (Eds.), Dublin.

SEAI 2011. Better Energy Homes Scheme-Contractors Code of Practive and Standards and Specifications Guidelines. Version 5.0. Dublin: The Sustainable Authority of Ireland.

Shipworth, M., Firth, S.K., Gentry, M.I., Wright, A.J., Shipworth, D.T., Lomas, K.J. 2010. Central heating thermostat settings and timing: building dempgraphics. Building Research and Information 38, 50-69.

Sinnott, D., Dyer, M., 2012. Air-tightness field data for dwellings in Ireland. Building and Environment 51, 269-275.

Stephen, R.K., 1998. Air Tightness in UK Dwellings: BRE's Test Results and their Significance. British Research Establishment, London, UK.

Uglow, C.E. 1989. Background Ventilation of Dwellings: A Review. In: Establishment, B. R. (Ed.). Garston, Watford, UK. 